REFERENCES:

[1] Dagfinrud, et al. Arthritis Care Res. 2011;63(4):597-603.

[2] Niedermann, et al. Arthritis Care Res. 2018. Doi: :10.1002/acr.23705

Acknowledgement: The authors thank the Dutch Arthritis Society for funding this study and for thinking along from the patients' perspective. They also thank all participants, coordinators, boards and guiding therapists from the four included SGE regions.

Disclosure of Interests: None declared

DOI: 10.1136/annrheumdis-2019-eular.3718

\section{FRI0394 MAINTAINED CLINICAL REMISSION IN ANKYLOSING SPONDYLITIS PATIENTS SWITCHED FROM REFERENCE INFLIXIMABTO ITS BIOSIMILAR. AN 18- MONTH COMPARATIVE OPEN-LABEL STUDY}

Evripidis Kaltsonoudis $^{1}$, Eleftherios Pelechas ${ }^{2}$, Paraskevi Voulgari ${ }^{1}$, Alexandros Drosos ${ }^{1}$, We have no working group for this abstract. ${ }^{1}$ Rheumatology Clinic, University of loannina, Ioannina, Greece, Department of Internal Medicine, Medical School, University of loannina, loannina, Greece; ${ }^{1}$ Rheumatology Clinic, University of loannina, Ioannina, Greece, Department of Internal Medicine, Medical School, University of loannina, Ioannina, Greece

Background: switching from reference infliximab $(R I)$ to biosimilar infliximab (BI) had no detrimental effects on efficacy and safety compared to continuous Rl. However, long-term follow-up data is missing.

Objectives: the aim of this study was to evaluate if $\mathrm{BI}$ is equivalent to $\mathrm{RI}$ to maintain patients with Ankylosing Spondylitis (AS) in clinical remission, in a long-term fashion.

Methods: one hundred and nine consecutive unselected AS patients were investigated. All, followed-up at predefined times receiving RI $(5 \mathrm{mg} / \mathrm{kg} / 8$ weeks) and were naïve to other biologics. Patients who were in clinical remission were asked to switch from $\mathrm{Rl}$ to $\mathrm{BI}$ using the same therapeutic dose. Patients switched to $\mathrm{Bl}$ were compared with a match control group receiving continuous $\mathrm{RI}$. During follow-up the demographic, clinical, laboratory parameters and comorbidities were all recorded for at least 18 months. Disease activity was measured using the Bath Ankylosing Spondylitis activity index (BASDAI), and the Ankylosing Spondylitis disease activity score (ASDAS), using the C-reactive protein. Remission was defined if patients achieved BASDAI $<4$ and ASDAS $<1.3$.

Results: twenty-one patients were excluded, nine because had no clinical remission and twelve because refused to switch. Thus, 88 were evaluated. From those, 45 switched to $\mathrm{BI}$, while 43 continued receiving $\mathrm{RI}$. There were no differences between groups regarding demographic, clinical and laboratory parameters. All patients were in clinical remission (BASDAI $<4$ and ASDAS <1.3). During follow-up, five patients from the switched group and three from the maintenance group discontinued the study. Four patients receiving $\mathrm{BI}$ presented nocebo effects and were switched back to the Rl. Three responded well, while the fourth did not. After 18 months of treatment, all patients in both groups remained in clinical remission. No significant adverse events were noted between groups.

Conclusion: $\mathrm{BI}$ is equivalent to $\mathrm{RI}$ in maintaining $\mathrm{AS}$ in clinical remission for at least 18 months.

Acknowledgement: We have no acknowledegement for this abstract

Disclosure of Interests: None declared

DOI: 10.1136/annrheumdis-2019-eular.4007

\section{FRI0395 $\quad$ SWITCHING RATE OF ANTI-TNF AGENTS IN SPONDYLOARTHRITIS PATIENTS: TREASURE - REAL LIFE DATA}

Umut Kalyoncu, Sedat Kiraz, Abdulsamet Erden, Orhan Küçükşahin, Timuçin Kaşifoğlu, Ediz Dalkılıç, Cemal Bes, Nilüfer Alpay Kanıtez, Hakan Emmungil, Pamir Atagündüz, Belkıs Nihan Coşkun, Burcu Yağız, Süleyman Serdar Koca, Muhammet Çınar, Aşkın Ateş, Servet Akar, Onay Gercik, Duygu Ersözlü, Veli Yazısız, Gezmiş Kimyon, Müge Aydın, Rıdvan Mercan, Burak Öz, Nazife Sule Yasar Bilge, Zeynel Abidin Akar, Omer Karadag, Ayse Bahar Kelesoglu Dincer, Sedat Yilmaz, Ufuk İlgen, Yavuz Pehlivan, Ender Terzioğlu, Levent Kılıç, Şükran Erten, Ali İhsan Ertenli. On Behalf of TReasure biological registry, Ankara, Turkey

Background: In spondyloarthritis (SpA), biologic DMARDs are important treatment options in resistant patients. Inefficacy or side effects may cause switching between these drugs.

Objectives: This study aimed to determine features of patients switching from one biologic agent to another in SpA treatment and to investigate associated reasons.
Methods: This multicenter, prospective observational cohort study used the TReasure database in which web-based registration of rheumatoid arthritis and $\mathrm{SpA}$ patients are being performed in 15 centers across different regions of Turkey. In this study, data of SpA patients switching from one biologic agent to another were analyzed. Demographic and clin ical data, follow-up duration, time to switch, and reasons for switching were retrieved from the database. Kaplan-Meier analysis was performed to show drug retention rates and Cox regression analysis was performed to investigate the factors affecting switching

Results: Of the included 3138 SpA patients, 1165 (37.1\%) switched to another biologic agent (switched group) and 1973 (62.9\%) continued to receive their current therapies (continued group). The median follow-up duration of all patients was 3.8 years and the median time to switch was 1.0 years (0-13.4 years). According to the distribution of comorbidities, the rates of patients having diabetes mellitus, hyperlipidemia, asthma, gastrointestinal bleeding, and cancer were significantly higher in the switched group than those of in the continued group $(8.4 \%$ vs. $5.8 \%$, $\mathrm{p}=0.006 ; 14.5 \%$ vs. $9.2 \%, \mathrm{p}<0.001 ; 15.6 \%$ vs. $6.2 \%, \mathrm{p}<0.001 ; 3.2 \%$ vs. $1.8 \%, p=0.018$; and $1.0 \%$ vs. $0.3 \%, p=0.019$; respectively). Features of the patients are presented in Table 1. Cox regression analysis revealed that female gender $\mathrm{HR} 1.47(95 \% \mathrm{Cl} 1.24-1.75), \quad \mathrm{p}<0.001$, disease dura tion $\mathrm{HR} 1.016(95 \% \mathrm{Cl} 1.00-1.03), \mathrm{p}=0.009$, and BASDAI score HR 1.095 $(95 \% \mathrm{Cl} 1.05-1.14), \quad p<0.001$ were the significant increasing factors for switching from one biologic agent to another.

In the switched group $(n=1165)$, the main reasons for switching were secondary inefficacy $(n=351)$, primary inefficacy $(n=328)$, and side effects $(n=267)$ followed by primary or secondary unknown inefficacy $(n=57)$, physician's request $(n=45)$, patient's demand $(n=36)$, willing to be preg nant $(n=9)$, other $(n=37)$, and unknown $(n=70)$.

\begin{tabular}{lcccr}
\hline & Adalimumab & Etanersept & Golimumab & Infliximab \\
\hline Etanersept & 0,329 & & & \\
Golimumab & $\mathbf{0 , 0 1 6}$ & $\mathbf{0 , 0 0 4}$ & & \\
Infliximab & $\mathbf{0 , 0 0 3}$ & 0,069 & $<\mathbf{0 , 0 0 1}$ & \\
Certolizumab & $\mathbf{0 , 0 0 2}$ & $<\mathbf{0 , 0 0 1}$ & 0,197 & $<\mathbf{0 , 0 0 1}$ \\
\hline
\end{tabular}

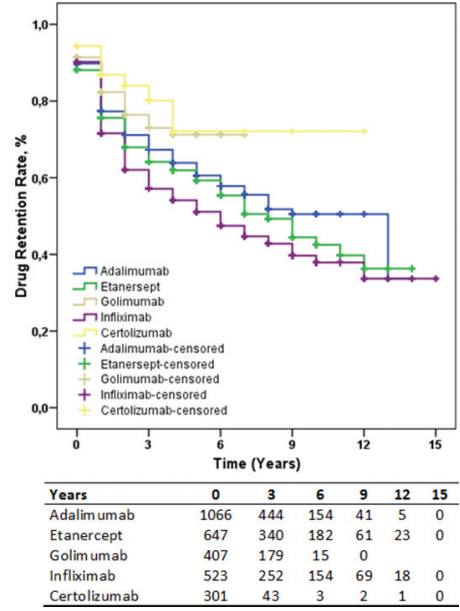

Figure 1. Kaplan-Meier curve for drug retention rates in the switched group

Conclusion: In SpA patients, switching was frequent between anti-TNF agents and the median time to first switch was 1 year. Female gender, short disease duration, and lower BASDAl score were found to be the significant factors affecting switching from the anti-TNF agent used at first. The main reasons for this switching were primary $(29.0 \%)$ and secondary $(31.0 \%)$ inefficacy followed by side effects $(23.6 \%)$. Switching between subcutaneous anti-TNF agents is generally less than switching from infliximab to another biologic agent.

Disclosure of Interests: Umut Kalyoncu Grant/research support from: MSD, Roche, UCB, Novartis and Pfizer, Consultant for: MSD, Abbvie Roche, UCB, Novartis, Pfizer and Abdi Ibrahim, Speakers bureau: MSD, Abbvie, Roche, UCB, Novartis, Pfizer and Abdi Ibrahim, Sedat Kiraz: None declared, Abdulsamet Erden: None declared, Orhan Küçükşahin None declared, Timuçin Kaşifoğlu: None declared, Ediz Dalkılıç Grant research support from: MSD and Abbvie, Consultant for: MSD, Abbvie, Roche, UCB, Pfizer and Novartis, Speakers bureau: MSD, Abbvie,Roche, UCB, Pfizer and Novartis, Cemal Bes: None declared, Nilüfer Alpay Kanıtez: None declared, Hakan Emmungil Grant/research support from: MSD 